$$
\text { Emerald } \begin{aligned}
& \text { European Journal of } \\
& \text { Innovation Management }
\end{aligned}
$$

\title{
OPEN ACCELERATORS FOR START-UPS SUCCESS: A CASE STUDY
}

\begin{tabular}{|r|l|}
\hline Journal: & European Journal of Innovation Management \\
\hline Manuscript ID & EJIM-10-2015-0113 \\
\hline Manuscript Type: & Original Article \\
\hline Keywords: & Business Failures, Case Studies, Open innovation, Accelerators, Strat-ups \\
\hline \multicolumn{2}{|r}{} \\
\hline
\end{tabular}

SCHOLARONE ${ }^{\text {MT }}$

Manuscripts 


\title{
OPEN ACCELERATORS FOR START-UPS SUCCESS: A CASE STUDY
}

\begin{abstract}
Purpose

This paper wants to investigate how the context of open innovation offered by accelerators can affect successful growth of start-ups. We explore practices and tools of accelerators sustaining startups in their innovation process to increase survival probability with the aim of addressing the following research questions: How can start-ups benefit from participation in an accelerator programme from an open innovation perspective?

Design/methodology/approach

We carried out a review of literatures on failures in start-ups and on major practices in Open Innovation paradigm, declining them in the context of accelerators. Given the absence of a literature on accelerators practices for supporting start-ups, we collected them searching on the platform f6s.com. Aiming at a comprehensive understanding on how the open environment inside the accelerator influences a start-up' survival (or even success) mitigating the probability of failure, we conducted an exploratory and inductive case study in an English accelerator.

Findings

We show the open innovation practices mediated by accelerator and the ones that are not covered but that can benefit start-ups survival. From the other side opening up innovation process cannot address all main causes of failures. Intrinsic characteristics of founders team seem not to be addressed by an open approach, neither participation to an accelerator program. Main effective practices, such as dyadic co-creation with accelerator network partners and crowdsourcing, are revealed to address mostly lacks or wrong direction in product, marketing and relative managerial abilities, which are not usually owned by a start-up due to its "newness".

Originality/value

The paper is the first one that studies accelerators, start-ups and open innovation.
\end{abstract}




\section{Introduction}

Open Innovation paradigm (Chesbrough, 2003) requires firms to open up their innovation process leveraging on both internal and external sources of knowledge and realizing new business opportunities (Chesbrough and Rosenbloom, 2002).

Literature focuses mainly on how large corporations engage with start-ups. Weiblen and Chesbrough (2015) examine for example balancing speed and agility against control and strategic direction. They describe how "when it comes to agility, start-ups have an edge over large corporations - whereas large corporations sit on resources which start-ups can only dream of". Among external sources of innovation, start-ups play a key role in value networks of incumbent firms (Chesbrough, 2006; Shane, 2001), since they are founded to convert innovative ideas into commercial products.

This paper focuses instead on the other side: how start-ups benefit from open innovation practices. Schumpeter (1934) underlined the importance of new firms as key drivers of economic development (e.g. job creation - Birch, 1987), industry evolution (in the sense that they renovate the market and facilitate competition) and innovation (Beckman et al., 2012).

However, many new firms fail in the early stages of their life (Dahl and Reichstein, 2007) and few grow to medium size (Kirchhoff et al., 2013). Different factors have been studied by scholars to explain the survival or failure of start-ups (Phillips and Kirchhoff, 1989; Shane, 2003). One of the critical factors is openness to external knowledge sources, where its importance is connected to the limitations of the normal small size of start-ups that derives in increased costs of research and development and lack of resources (Dahlander and Gann, 2010; de Jong et al., 2010).

Open innovation implies leveraging external knowledge and commercialization opportunities by managing the knowledge flows across corporate boundaries (Chesbrough and Bogers, 2014; West and Bogers, 2014). Among innovation network actors, business incubation and venturing mechanisms received increasing attention in open innovation literature (Chesbrough, and Brunswicker, 2014; van de Vrande et al., 2009). Eftekhari and Bogers (2015) and Scillitoe and Chakrabarti (2010) demonstrate that being located in the open environment of a business incubator was one of the main factors affecting new ventures success in terms of survival, sales and employment growth and new collaborations. In fact, this kind of organisations was established with the aim of supporting and accelerating new entrepreneurial companies creation by offering them access to external networks of partners and resources (Pauwels et al., 2015). With their role in boosting new ventures, institutions such as incubators, accelerators and angel ventures are recognised as key players in promoting innovation and economic growth with effects on the overall innovation ecosystem (Isabelle, 2013).

This paper wants to investigate how the context of open innovation offered by accelerators can affect successful growth of start-ups. We explore practices and tools of accelerators sustaining startups in their innovation process to increase survival probability with the aim of addressing the following research questions: How can start-ups benefit from participation in an accelerator programme from an open innovation perspective?

\section{Theoretical background}

\section{Start-ups and failure}

Entrepreneurs create value by leveraging innovation to exploit new opportunities, create new product market domains and commercialize new technologies (Drucker, 1985; Miles, 2005). In fact, the term start-up implies that a venture is new and may be seeking to create a new market. Starting a new business means creating innovation (an innovative product or service) realising a scalable and repeatable business model (Blank, 2010; Blank and Dorf, 2012) in a context of extreme uncertainty and higher competitive pressure (Ries, 2011; Trimi and Berbegal-Mirabent, 2012). A business model describes how strategy is concretely implemented (Casadesus-Masanell and Ricart, 2010), and then how a company creates, delivers and captures value (Osterwalder and Pigneur, 2010). 
Start-ups are defined as organisations built to search for a business model that is (1) scalable, as the customer base should be easily increased with a gain greater than the expenditure for customer acquisition, (2) repeatable in time, and (3) profitable in terms of return from invested money (Blank, 2010; Blank and Dorf, 2012). Often many start-ups fail before they fulfil their entire business potential (CB Insights, 2015; Crowne, 2002; Feinleib, 2011; Giardino et al., 2014; Ries, 2011).

Since start-ups introduce new products or services that put in doubt the positions of incumbent firms, they are often considered the sources of "creative destruction" (Criscuolo et al., 2012) and often more innovative than established firms (Shane, 2008). Despite that, statistics suggest that business mortality of start-ups can be as high as $70 \%$ in the first five years, depending on the specific industry in question (Gruber and Enkel, 2004). Failure for a start-up means closing down (Bruno et al., 1992), divesting through sale to another corporation or to individuals (Bruno et al., 1992), not achieving a worthwhile return on the investments (Crowne, 2002).

Start-ups have in fact both limited resources and numerous investment needs, including $R \& D$, organization building and market development but also management skills. A lack of knowledge of how to identify and exploit opportunities may pose a challenge to entrepreneurs' decision-making (Alvarez and Barney, 2010). Normally, start-ups lack of market visibility as well as connectedness to resource networks due to their "newness" and need support in promoting innovation and entrepreneurship (Wong et al., 2005). Among SMEs, start-ups are not always able to exploit opportunities for innovation offered by the mechanisms of external knowledge sourcing (Cohen and Levinthal, 1990) and external learning (Almeida et al., 2003).

Determinants of start-ups failure have been studied in literature with reference to different profiles of founders and to different industries (e.g. Cooper et al., 2014) or to a single industry (e.g. Crowne (2002) and Giardino et al. (2014) in the software development and Shah et al. (2008) in the micro- and nanotechnology one). Table 1 collect main factors driving start-ups failure in scientific literature, making evidence of the most studied and providing a classification based on their underlying similarity in the scope.

\section{Table 1 - Determinant factors of start-ups failure in literature}

Classification of determinants of failure reflects the main start-ups features revealing their potential and assessed during selections for funding, i.e. product or service characteristics, mechanisms of business development, personality characteristics and experience of individuals (entrepreneur / founders team), effect of environmental factors (such as market and financial characteristics) (Afful-Dadzie et al., 2015; Wong et al., 2005).

Scholars observed a combination of factors affecting start-ups failure of success - while there is not a predominant one - with different weights and importance evaluated by interviewed founders. In particular, Zacharakis et al. (1999) observed that new venture failure were attributed mostly to internal and firm-specific factors. Teal and Hofer (2003) considered also industry structure and dynamics as key determinant.

An innovative product or service presuming market acceptance (Bruno and Leidecker, 1988) is one of the most considerable factors when founding a new business. This is strictly linked to a missing o low marketing strategy and absence of awareness of understanding customers real needs and then constantly collect their feedbacks.

Another requirement investigated by many authors is the attention to financial details, such as the risk of running out of cash (CB Insights, 2015) or having too expenses (Shah et al., 2008) also when the new venture succeed in attracting investors. Also the amount of initial capital is a key issue, since it is related to the initial strategy that might be pursued (Cooper et al., 1994).

Founders' team choice and emergent dynamics are also a critical issue, in particular as regards individual skills specialisation (Crowne, 2002). Finally, personal backgrounds in terms of education - that relates to knowledge, skills, problem-solving ability, discipline, motivation, self-confidence is also one of the most studied among entrepreneurial variables (Cooper et al., 1994). 


\section{Start-ups and Open Innovation}

As a consequence that an important problem for start-ups is knowledge for decision making, Powell et al. (1996) and von Hippel (1998) find that varied access to distributed knowledge is critical for new ventures performance. This concept is expanded by Chesbrough (2003) in his argument that the increasing relevance of external resources augurs a new model of open (as opposed to closed) innovation for firms. The valuable advantages of opening up the innovation process to the external context is widely acknowledged (Boudreau and Lakhani, 2009) and proved both for large and small-medium-size enterprises (SMEs) (Brunswicker and Vanhaverbeke, 2015; Huizingh, 2011).

But do also start-ups benefit from participating in open innovation environments and in contributing their own resources to their development?

Work on the strategies of firms' participating in open systems remains less developed (Lerner and Tirole, 2005). Wagespack and Fleming (2009) study why a start-up should participate in an open community, proposing ways that participation might increase a start-up's chances of a liquidity event. These are related to knowledge and reputation (simply attending physical meetings of the community and endorsement of the start-up's technology standard), entrepreneurship/development (openly developing the start-up's technology within the community) and networking (having start-up's members elected to leadership positions). Recently, Eftekhari and Bogers (2015) explored how an open approach to start-ups creation - purposefully managing knowledge flows across the venture's organizational boundary - can be beneficial for start-up entrepreneurs. They find that ecosystem collaboration, user involvement and an open environment directly influence new venture survival, and that their effects were moderated by the entrepreneurs' open mindset.

Given a resource-constrained context, start-ups' survival and success is dependent on a combination of internal knowledge and external resources (Eisenhardt and Schoonhoven, 1996; Presutti et al., 2011). Having a solid network is emphasized as one of the key factors influencing the emergence and successful development of a start-up (Rothschild and Darr, 2005). Networks are critical for the survival and growth of a small firm because they can provide access to e.g. information, advice and influence as well as resources held by others (e.g. Hoang and Antoncic, 2003). Diverse external knowledge-sourcing relationships are an important determinant of entrepreneurs' ability to identify more (and more varied) market opportunities (Gruber et al., 2013). Founders have the possibility to gain access to resources more cheaply by using their network contacts than if they were in a situation where they had to resort to market transactions. The entrepreneurs can acquire resources from the network that would not be available via market transaction at all (Witt, 2004).

Physical proximity to other companies can play a beneficial role, as they can catalyze the entrepreneurial process and also facilitate collaboration among firms (European Commission, 2002). This points at the fact that the physical incubator environment is conducive to the crossfertilization of ideas, advice and networking.

In this line, openness to external knowledge sources and creation of business relationships for innovation have been recognised as two crucial factors in the early stages of firm development (Carlsson and Corvello, 2011; Eftekhari and Bogers, 2015; Kask and Linton, 2013). The general network (Chesbrough and Bogers, 2014), the frequency of interactions with external partners (Harms et al., 2009) and the management of various and diverse inflows of new ideas and intellectual property (Chesbrough, 2003; Gruber et al., 2013) have an impact on start-ups' acquisition and exploration of external knowledge.

Taken from the review of West and Bogers (2013), Chesbrough and Brunswicker (2014) and our literature review, we derived the main open innovation practices of SMEs described in the literature. We mostly examined the in-bound and coupled modes of open innovation because we wanted to identify practices that benefit start-ups. 
Table 2 - Main in-bound and coupled Open Innovation practices in SMEs

Start-ups and Accelerators

Accelerators are a recent and rising phenomenon, driven by the changing economics of early stage start-ups, especially the tech ones, which benefit from a dramatic decrease in costs of experimentation (Pauwels et al., 2015). From the first Y Combinator founded by Graham in $2005-$ defined as the most successful and copied accelerator (Christiansen, 2009; Pauwels et al., 2015) this new kind of incubating organisations for new ventures is rapidly growing in number and expanding from US to Europe (Christiansen, 2009; Cohen and Hochberg, 2014).

Accelerators derive many of their characteristics from the business incubators, focusing on firms at the earliest stage of development and providing them entrepreneurial support services, but their programmes have distinguishing characteristics (Cohen and Hochberg, 2014; Miller and Bound, 2011; Pauwels et al., 2015). In particular they provide a time-limited and intense mentorship and education programme, allowing entrepreneurs to focus attention and to reduce dependence from accelerators - leading in this way to quicker growth or quicker failure (that can be beneficial in moving to a higher-value opportunity) (Cohen and Hochberg, 2014). The application process is worldwide open and highly competitive, and focus on small teams - with technical background (Christiansen, 2009) - instead of individual founders and involved in classes or batches of start-ups. Moreover, they provide pre-seed investment, in exchange of equity stakes of participating ventures. Many accelerators are indeed for-profit (Isabelle, 2013) and private owners often have extensive experience as entrepreneurs or angel investors (Cohen and Hochberg, 2014), considering also portfolio perspective (Kim and Wagman, 2014). Finally, main valuable aspect is provision of intense mentoring and advice, and of numerous opportunities of networking with investors and other start-ups, embedded in a supportive peer-to-peer environment and entrepreneurial culture (Christiansen, 2009; Cohen and Hochberg, 2014; Hoffman and Radojevich-Kelley, 2012).

In this sense, successful accelerator programmes demonstrated having a key role in boosting the local start-up ecosystem they belong to and acting as focal points for introducing and building new network ties between founders, investors and other stakeholders (Miller and Bound, 2011). Even though the phenomenon has received growing interest by practitioners, there have been few attempts for formal analysis and research in scientific literature.

\section{Research gap and questions}

Openness as a way to accelerate internal innovation activities has attracted increasing attention in both research and practice (West and Bogers, 2014). As regards open innovation, scholars (e.g. van de Vrande et al., 2009; Lee et al., 2010) call for further research in open innovation field to fully understand how its adoption can play a role in different types of SMEs - e.g. start-ups - and in different phases of companies' growth. Moreover, start-ups' success can be significantly challenged by the innovation ecosystem in which it is embedded (Nambisan and Baron, 2013). Therefore more attention on impacts on ventures participating to incubation or acceleration programmes is also required (Isabelle, 2013). Despite start-ups benefit significantly from external sources of innovation, this topic has not received much attention in the open innovation literature (van de Vrande et al., 2009; Chesbrough and Bogers, 2014).

While previous literature (e.g. Grimaldi and Grandi, 2005; Lendner and Dowling, 2007; McAdam and Marlow, 2007; Schwartz, 2013) is mostly focused on incubators and their role in addressing start-ups failure, research on accelerators received attention only recently (Cohen and Hochberg, 2014; Isabelle, 2013; Kim and Wagman, 2014; Malek et al., 2014; Miller and Bound, 2011; Pauwels et al., 2015). Scientific literature on accelerators is recent and lacks of comprehensive data sources (Cohen and Hochberg, 2014) and of consistent theoretical lens to study the phenomenon (Pauwels et al., 2015). Miller and Bound (2011) conduct a first deep study on evolution, benefits and business models of accelerators and their programmes but they do not focus 
on services and tools offered to start-ups. Later Cohen and Hochberg (2014) compare their key features with the ones by incubators and angel investors in terms of programmes duration, business model and education and mentorship offered; while Isabelle (2013) focus on how these differences influence new entrepreneurs choice in joining them. Malek et al. (2014) identify key capabilities of accelerators classifying them in $R \& D$ focused, technology enabled, market enabled, and network enabled ones, limiting them to clean tech industry. Kim and Wagman (2014) focus on the financial perspective with a model on the choice of portfolio. Finally, Pauwels et al. (2015) delineate different models of accelerators based on heterogeneity of strategies and operations - the "ecosystem builder", the "deal-flow maker" and "welfare stimulator" - but they do not investigate effects of different types of organisations on accelerated start-ups. Therefore, a deep analysis on accelerators practices and their effects on graduated start-ups is still missing.

We address this research gap by investigating how openness to external knowledge sources can mitigate start-up failure. Starting from the above mentioned, this paper aims to address both open innovation literature and entrepreneurship literature by answering the research questions formulated as follows:

How do accelerators mediate open innovation practices to address potential failure of start-ups?

\section{Methodology}

For the purpose of this study, a single case study (Yin, 2003) was performed. This choice is supported by the exploratory finalities of our research (Eisenhardt, 1989). Given the absence of a literature on accelerators practices for supporting start-ups, the first step of the research was based on Seed-DB, an online database of accelerators and their graduated companies, and on FS6.com, an online platform that supports a community of accelerators, potential investors and other funding institutions for start-up owners. From these sources, we identified the first list of potential interesting cases starting from their specific description. In this case, the selection was restricted to the organisations that fully fit the key features of accelerators identified in literature (Christiansen, 2009; Cohen and Hochberg, 2014; Miller and Bound, 2011; Pauwels et al., 2015), as following:

1) an open, rigorous and highly competitive application process;

2) limited-duration and intensive programmes (lasting around three months);

3) involvement of batches or classes of start-ups instead of individual ones;

and generally:

4) offering pre-seed investment in exchange for equity stakes;

5) ending with a public pitch event or "demo-day".

Since accelerators demonstrated having a specific geographical focus and operating autonomously at local level (Pauwels et al., 2015), we further add the criterion of selecting institutions located in a single specific country. As country base we selected UK, which stands out as one of the most attractive thanks to: (1) the special visa to live and work promoted by the Government for foreign company founders accepted onto an English accelerator programme (Miller and Bound, 2011) (2) the important presence of business angels and venture capitalists that demonstrated performing better than US in return on investments (Lerner et al., 2011), and (3) the acknowledgment of London as one of the leading accelerator regions in Europe (Pauwels et al., 2015).

Aiming at a comprehensive understanding on how the open attitude inside the accelerator influences a start-up' survival (or even success) mitigating the probability of failure, we conducted an exploratory and inductive case study (Eisenhardt, 1989; Yin, 2009) in an English accelerator. The sources have been interviews and secondary sources (mainly online databases and institutional websites).

The case study was analysed by tracking the 12 weeks programme offered by the English accelerator Searchcamp for early stage internet start-ups in 2013. Among the initial eight start-ups 


\section{Findings}

The final dataset resulting from the research on online databases includes a total of 24 accelerators from UK. Table 3 lists the main features of selected accelerators: name, location, industry, initial investment, share of equity required, duration of the programme, number of start-ups participating in each batch or class and main practices and services offered in the programme package.

\section{Table 3 - UK accelerators: main features and services}

Initial investments support the initial costs of startupping process, allowing co-founders maintain the focus on their business development, without having to look for a second job (Miller and Bound, 2011). It emerges that most of accelerators focus on generic industries or sectors (Pauwels et al., 2015), providing mentoring that aims to cover lacks in general management and entrepreneurial skills most than specialisation in a very specific industry or sector. The amount of initial investment is limited (Christiansen, 2009; Pauwels et al., 2015) and varies from 16.000 to $30.000 €-$ except for Accelerator Accademy, that requires an initial payment eventually reimbursed at the end of the programme. Ignite100, SearchCamp, Startup Bootcamp and True Start include also a supplemental package of services - i.e. room and board, meeting rooms and prepaid server services - that reaches a value of $450.000 €$ in the case of Startup Bootcamp. In return to this initial investment accelerators acquire from a minimum of 5\% to a maximum of $15 \%$ of start-ups shares aiming at an economic return after start-up acquisition by an incumbent firm (Cohen and Hochberg, 2014).

Most of the accelerators provide intense programmes of an average of 3 months, involving up to 20 start-ups per batch and then fostering peer-to-peer learning (Pauwels et al., 2015), sharing of experiences and emergent ideas from one side and of some kind of expenditures - e.g. legal - on the other (Miller and Bound, 2011).

Among the listed accelerators, SearchCamp offers one the most complete package - beyond other supplemental services for personal need of team members as mentioned before. Beyond the provision of office and co-working space tailored for start-ups (Hoffman and Radojevich-Kelley, 2012; Miller and Bound, 2011), networking and mentoring represent its main valuable support. In particular, networking activities were divided according to their scope in: 
a) Tax and legal advice: network of consultants, law and tax firms with consolidated experience in the field, with which accelerators granted packages of services beneficial to start-ups;

b) Start-ups: the accelerator organises meetings and special events (that can also be competitions) where entrepreneurs, professionals and start-ups from the same or from different industries have the opportunity to share information and feedbacks on their respective activities and to create new potential synergies;

c) Investors: most accelerators have an own network of business angels and venture capitals willing to provide funding to the most promising start-ups participating at the programme;

d) Tech partners: accelerator partners that support product or service technical development, e.g. with test and prototyping services. The collaboration during the program can be further converted in long-term partnerships for product or service co-development between successful start-ups and tech partners became first level suppliers.

As regards mentoring activities, we distinguish between:

e) Education / workshops: workshops and classes dedicated to specific issues - both technical and industry-related and both dedicated to management and entrepreneurial topics - and delivered by coaches, entrepreneurs and technical experts.

f) Mentorship: mentors work in very close contact with start-up founders during the whole programme offering advice, recommendation and feedbacks based on their previous experience as entrepreneurs. Mentors play also a key role during the process of selection.

In Table 4 specific tools adopted by Searchcamp accelerator for each above mentioned service are listed and described.

\section{Table 4 - Services and tools in Searchcamp accelerator}

In the following pages, tools efficacy is discussed in one of the firm successfully acquired at the end of the program, named Tangle. This start-up was founded by four engineering and computer science students with the aim of developing an application for business dating, based on geolocalisation and on real interest of people in meeting up business people met in occasions such as conferences and business meetings. During their acceleration course, they succeed in changing properly product and target market in an online application for dating people identified as interesting and met during the day.

The founders worked on their product development 7 days a week in the office space offered, where they could benefit of the peer-to-peer interaction and cross learning from experiences and knowledge sharing also with other teams. The office was often used also to meet advisors and mentors for further consolidate relationships and benefit of their advice in an informal environment.

Also potential investors of Searchcamp network, such as business angels and venture capitalists, regularly visited the co-working space in order to know thoroughly the different business ideas and to monitor their progress. Tangle labs succeeded in attracting two investors in consecutive moments and, thanks to their funding, they could improve constantly their product and testing marketing actions, that further allowed to improve product fit to the market.

Due to its focus of internet start-ups, a resident CTO (Chief Technology Officer) and numerous computer engineers constitute Searchcamp tech network. Tangle team was able to benefit from the co-development of their product with computer experts that helped improving programming language at the base of the application. Teams had also the opportunity to participate to Demo Days where to present their product or service idea to a larger audience of investors. One of these events was organised in the Google Campus in London, where Tangle founders had the opportunity to getting in contact with other experts providing Gooogle online functionalities useful for their application.

Moreover, from the synergy among some of the present and the past teams of Searchcamp program and a group of mentors, a community of practice located in Middlesbrough was founded. 
This represented another valuable opportunity to share expertise and experiences among professionals and other actors of the same industry.

As regards founders education, workshops and lessons delivered were focused on both technical issues (such as software development) and managerial ones (such as how to develop properly a business model following Osterwalder and Pigneur's (2010) method). For instance in Tangle case, lessons on analytics tools were useful as members learnt how to adopt them in order to daily or weekly monitor number, localisation and behaviour (e.g. time spent on the application and actions made) of application users. Advices on available strategic tools, need of customers centrality and choose of the right marketing strategy, led the start-up team in conducting numerous interviews in order to identify target market, which they found out being young people between 18 and 34 years. Potential customer feedbacks and questionnaire results showed that $30 \%$ of the sample have difficulty in approaching face to face with a new person and $70 \%$ regret not having had the opportunity to get in touch with a person met during the day. This data were further elaborated with outputs of system monitoring customers behaviour in order to improve product marketability.

Finally, the intense interaction with the pool of high quality mentors offering support and share of experiences as entrepreneurs, allowed to consolidate the knowledge acquired during the program and to apply it systematically. Tangle demonstrated being able to recognise the value of the whole contributions offered by the accelerator, to assimilate it and then to apply it in improving their product and their business strategy. This carried out to the successful acquisition by a Scottish corporation in June 2014.

\section{Discussion}

While proposing innovative products and services, start-ups lack of market visibility as well as connectedness to resource networks and need support in promoting innovation and entrepreneurship (Wong et al., 2005). Search of investors and in general partners allows to increase probability of start-up survival thanks to their provision of larger and deeper expertise, experience and resources (Cooper et al., 1994).

In this sense, accelerators play the role of intermediary between the new ventures and the external sources of knowledge and resources to support their development process. They provide a network of high quality external experts and entrepreneurs that are willing to share their experience and knowledge and to offer their money (in the case of investors) to make start-ups judged as innovative and high-potential growing successfully - and then to mitigate their possible causes of failure.

Opening up the innovation process to external sources is the base of the Open Innovation paradigm as theorised by Chesbrough (2003). In this line, efficacy of services and tools offered by accelerators from participating founders point of view can be evaluated in an open innovation perspective.

In Table 5, main services and tools of Searchcamp accelerator are crosschecked with SMEs practices of open innovation in order to highlight their validity as regards open innovation from start-ups perspective.

\section{Table 5 - Tools and practices of accelerator as open innovation practices}

It emerges that services offered by the accelerator meet most of the practices generally adopted from SMEs while opening their innovation process. Only mass customisation cannot find a correspondence in the accelerator tools, since it presumes a direct involvement of customers in the process of innovation (Stoetzel, 2012) and it strictly depends from start-ups main business.

Also the practices and tools offered by the accelerator that are not linked directly to an open innovation practice concern mostly technical and strategic issues that do not imply use of external 
sources of knowledge to innovate business. For instance, the Kanban Board is focused on optimising workflows and tax and legal advices are strictly direct to bureaucratic issues.

Other practices are linked to networking and external knowledge acquisition that benefit companies in innovating their product or services and then their business.

Use of a common office space, face-to-face meetings with mentors and feedbacks of tech partners are most valuable factors to access external knowledge. They represent a valuable opportunity to practice informal networking and technology brokering, getting in contact with potential partners for future collaborations and learn from innovative solutions developed by experts other new ventures.

Actually start-ups conclude accelerator programme with an own network - made by expertise and experience from different areas and even from different industries. Mentors, experts and other entrepreneurs of this network become the co-developers of the innovative product / service proposed by the start-up, that can be further improved both technically and both in making it marketable thanks to their feedbacks and suggestions.

The following table helps in further formulate the link between the open innovation practices mediated by accelerator tools and practices and the main potential causes of start-ups failures they are supposed to address.

\section{Table 6 - Open Innovation practices and accelerators tools for mitigating start-ups failure}

In Table 6, we show the open innovation practices mediated by accelerator and the ones that are not covered but that can benefit start-ups survival. For instance, mass customisation helps in addressing a specific marketing strategy and in customising products or services in order to meet customer requirements at their best. R\&D collaborations can be pursued also beyond accelerator boundaries by leveraging on a stronger market share in front of high dynamics market.

From the other side opening up innovation process cannot address all main causes of failures. Intrinsic characteristics of founders team seem not to be addressed by an open approach, neither participation to an accelerator program. In particular, personal background and problem relationship dynamics inside the team cannot be affected by the availability of external expertise, which instead can help in improving their technical and managerial skills.

Main effective practices, such as dyadic co-creation with accelerator network partners and crowdsourcing, are revealed to address mostly lacks or wrong direction in product, marketing and relative managerial abilities, which are not usually owned by a start-up due to its "newness".

In answering our research question, we can then formulate the following preposition:

Open innovation practices facilitated by tools and practises offered by accelerator address specific potential failure causes of start-ups participating to their programme, in particular the ones concerning product or services characteristics, target market / needs awareness, strategic focus and relative managerial and industry-specific know-how.

\section{Conclusions}

This work has important practical implications both for founders of early-stage ventures and for accelerators and other supporting institutions. This work has implications both from open innovation literature and from practitioners' point of view. By demonstrating the key role of accelerators in enhancing open innovation practices for start-ups, it offers a valuable perspective for entrepreneurs to valuable ways of obtaining the knowledge and the resources needed to better fulfil their business potential.

Even before evaluating the possibility of applying for an accelerator programme, start-ups should be aware of their business status. In this sense, the list of the most important failure drivers 
presented in Table 1 can represent a first checklist for potentially avoiding failure (Bruno and Leideckerand, 1998) redirecting start-up strategic process of evolution.

The obtained results revealed how the key practices offered by accelerators can foster openness to external knowledge sources in start-ups. In particular, the open environment offered by the accelerator conveys the effort of the start-up in creating an innovative product or service in collaboration with customers. From the literature point of view, we showed practices and tools toward an open innovation approach that have an effect on potentially mitigating start-ups' failures. Understanding these allows more effective policies to be drawn to encourage and stimulate entrepreneurial activities with growth potential.

The main limitation of the study is that it is based on a single case study. Further work of the authors is directed towards multiple case studies and a deep investigation of the single failure factors in an open innovation approach.

For a start-up, newness can derive in lack of specific roles and capabilities and lack of organisational structure. Smallness can derive in scarce resources, mainly human and financial ones. These are real challenges for management by the start-up itself and by the intermediary organisations (accelerators, incubators, policy system, etc.). An open innovation approach can mitigate many of these problems, by constructing knowledge and capabilities, building relationships, making the company less vulnerable, opening new possibilities and shifting the organization to a more favourable strategic position. 


\section{References}

Afful-Dadzie, E., Oplatková, Z.K. and Nabareseh, S. (2015), "Selecting Start-Up Businesses in a Public Venture Capital Financing using Fuzzy PROMETHEE", Procedia Computer Science, Vol. 60, pp. 63-72.

Almeida, P., Dokko, G. and Rosenkopf, L. (2003), "Start-up size and the mechanisms of external learning: Increasing opportunity and decreasing ability?", Research Policy, Vol. 32, pp. 301-315.

Alvarez, S.A. and Barney, J. (2010), "Entrepreneurship and Epistemology: The Philosophical Underpinnings of the Study of Entrepreneurial Opportunities", The Academy of Management Annals, Vol. 4, No. 1.

Beckman, C.M., Eisenhardt, K., Kotha, S., Meyer, A. and Rajagopalan, N. (2012), "The role of the entrepreneur in technology entrepreneurship", Strategic Entrepreneurship Journal, Vol. 6, No. 3, pp. 203-206.

Birch, D. (1987), Job creation in America, New York: The free press.

Blank, S. (2010), "What's a start-up? First Principles", available at http://steveblank.com/2010/01/25/whats-a-startupfirst-principles/ (accessed 31 August 2015).

Blank, S. and Dorf, B. (2012), The Startup Owner's Manual: The Step-By-Step Guide for Building a Great Company, K \& S Ranch, California.

Boudreau, K.J. and Lakhani, K.R. (2009), "How to manage outside innovation", MIT Sloan Management Review, Vol. 50 No. 4, pp. 69-76.

Bruno, A.V. and Leidecker, J.K. (1998), “Causes of new venture failure: 1960's vs. 1980's”, Business Horizons, Vol. 31, pp. 51-57.

Bruno, A.V., McQuarrie, E.F. and Torgrimson, C.G. (1992), "The evolution of new technology ventures over 20 years: Patterns of failure, merger, and survival”, Journal of Business Venturing, Vol. 7 No. 4, pp. 291-302.

Brunswicker, S. and Vanhaverbeke, W. (2015), “Open Innovation in Small and Medium-Sized Enterprises (SMEs): External Knowledge Sourcing Strategies and Internal Organizational Facilitators", Journal of Small Business Management, Vol. 53 No. 4, pp. 1241-1263.

Carlsson, S. and Corvello, V. (2011), “Open innovation”, European Journal of Innovation Management, Vol. 14 No. 4 , pp. 408-411.

Casadesus-Masanell, R. and Ricart, J.E. (2010), "From strategy to business models and onto tactics", Long Range Planning, Vol. 43 No. 2, pp. 195-215.

CB Insights (2015), “The Top 20 Reasons Startups Fail”, available at https://www.cbinsights.com/research-reports/The20-Reasons-Startups-Fail.pdf (accessed 31 August 2015).

Chesbrough, H. and Bogers, M. (2014), "Explicating open innovation: clarifying an emerging paradigm for understanding innovation", Chesbrough, H., Vanhaverbeke, W. and West, J. (Eds.), New Frontiers in Open Innovation, Oxford: Oxford University Press, Oxford, pp. 3-28.

Chesbrough, H. (2006), “Open Innovation: A New Paradigm for Understanding Industrial Innovation”, Chesbrough, H., Vanhaverbeke, W. and West, J. (Eds.), Open Innovation: Researching a New Paradigm, Oxford University Press, Oxford, pp. 1-12.

Chesbrough, H. and Brunswicker, S. (2014), “A Fad or a Phenomenon? The Adoption of Open Innovation Practices in Large Firms", Research-Technology Management, Vol. 57 No. 2, pp. 16-25.

Chesbrough, H.W. (2003), Open Innovation: The New Imperative for Creating and Profiting from Technology, Harvard Business School Press, Boston, MA.

Christiansen, J.D. (2009), "Copying Y Combinator: A framework for developing seed accelerator programmes", working paper, University of Cambridge, Cambridge, August.

Cohen, S. and Hochberg, Y. (2014), "Accelerating startups: The seed accelerator phenomenon", available at http://papers.ssrn.com/sol3/papers.cfm?abstract_id=2418000 (accessed 10 September 2015).

Cohen, W.M. and Levinthal, D.A (1990), "Absorptive capacity: a new perspective on learning and innovation", Administrative Science Quarterly, Vol. 35 No. 1, pp. 128-152.

Cooper, A.C., Gimeno-Gascon, F.J. and Woo, C.Y. (1994), "Initial human and financial capital as predictors of new venture performance”, Journal of Business Venturing, Vol. 9 No. 5, pp. 371-395.

Criscuolo P., Nicolaou, N. and Salter, A. (2012), "The elixir (or burden) of youth? Exploring differences in innovation between start-ups and established firms", Research policy, Vol. 41, pp. 319-333.

Crowne, M. (2002), "Why software product startups fail and what to do about it. Evolution of software product development in startup companies", in Proceedings of the International Engineering Management Conference (IEMC), IEEE, pp. 338-343.

Dahl, M.S. and Reichstein, T. (2007), “Are You Experienced?: prior experience and the survival of new organizations”, Industry and Innovation, Vol. 14, No. 5, pp. 497-511.

Dahlander, L. and Gann, D.M. (2010), "How open is innovation”, Research Policy, Vol. 39, No. 6, pp. 699-709.

de Jong, J.P.J. and Freel M. (2010), “Absorptive capacity and the reach of collaboration in high technology small firms", Research Policy, Vol. 39, No. 1, pp. 47-54.

Drucker, P.F. (1985), Innovation and Entrepreneurship, Harper and Row, New York.

Duchesneau, D.A. and Gartner, W.B. (1990), "A profile of new venture success and failure in an emerging industry", Journal of Business Venturing, Vol. 5 No. 5, pp. 297-312. 
Eftekhari, N. and Bogers, M. (2015), "Open for Entrepreneurship: How Open Innovation Can Foster New Venture Creation", Creativity and Innovation Management, to be published.

Eisenhardt, K.M. and Schoonhoven, C.B. (1996), "Resource-based view of strategic alliance formation: strategic and social effects in entrepreneurial firms", Organization Science, Vol. 7 No. 2, pp. 136-150.

Eisenhardt, K.M. (1989), "Building Theories from Case Study Research", Academy of Management Review, Vol. 4, pp. 532-550.

European Commission (2002), Benchmarking of business incubators, Brussels.

European Commission (2003), Entrepreneurship in Europe, Brussels.

Feinleib, D. (2011), Why Startups Fail: And How Yours Can Succeed, Apress, New York, NY.

Freeman, J. and Engel, J. (2007), "Models of innovation: Startups and mature corporations", California Management Review, Vol. 50 No. 1, pp. 94-119.

Giardino, C., Wang, X. and Abrahamsson, P. (2014), "Why Early-Stage Software Startups Fail: A Behavioral Framework", in Lassenius, C. and Smolander, K. (Eds.), Software Business. Towards Continuous Value Delivery, Springer International Publishing, Switzerland, pp. 27-41.

Grimaldi, R. and Grandi, A. (2005), "Business incubators and new venture creation: an assessment of incubating models", Technovation, Vol. 25 No. 2, pp. 111-121.

Gruber, M., Henkel, J. (2006) "New ventures based on open innovation - An empirical analysis of startup firms in embedded Linux", International journal of technology management, Vol. 33 No. 4, pp. 356-372.

Gruber, M., MacMillan, I. and Thompson, J.D. (2013), "Escaping the prior knowledge corridor: what shapes the number and variety of market opportunities identified before market entry of technology start-ups?", Organization Science, Vol. 24 No. 1, pp. 280-300.

Hargadon, A. and Sutton, R.I. (1997), "Technology brokering and innovation in a product development firm", Administrative Science Quarterly, Vol. 42, No. 4, pp. 716-749.

Harms, R., Kraus, S. and Schwarz, E.J. (2009), "The suitability of the configuration approach in entrepreneurship research", Entrepreneurship and Regional Development, Vol. 21 No. 1, pp. 25-47.

Hoang H. and Antoncic B. (2003), "Network-based research in entrepreneurship - A critical review", Journal of Business Venturing, Vol. 18 No. 2, pp. 165-187.

Hoffman, D.L. and Radojevich-Kelley, N. (2012), "Analysis of Accelerator Companies: An Exploratory Case Study of Their Programs, Processes, and Early Results", Small Business Institute Journal, Vol. 8 No. 2, pp. 54-70.

Huizingh, E.K.R.E. (2011), "Open innovation: State of the art and future perspectives", Technovation, Vol. 31, pp. 2-9.

Isabelle, D.A. (2013), "Key Factors Affecting a Technology Entrepreneur's Choice of Incubator or Accelerator", Technology Innovation Management Review, pp. 16-22.

Kask, J. and Linton, G. (2013), "Business mating: when startups get it right", Journal of Small Business and Entrepreneurship, Vol. 26 No. 5, pp. 511-536.

Kim, J. and Wagman, L. (2014), "Portfolio size and information disclosure: An analysis of startup accelerators", Journal of Corporate Finance, Vol. 29, pp. 520-534.

Kirchhoff, C.J., Lemos, M.C. and Dessai, S. (2013), "Actionable knowledge for environmental decision making: broadening the usability of climate science", Annual Review of Environment and Resources, Vol. 38 No. 1, pp. 393414.

Laursen, K. and Salter, A. (2006), "Open for innovation: the role of openness in explaining innovation performance among UK manufacturing firms", Strategic Management Journal, Vol. 27 No. 2, pp. 131-150.

Lee, S., Park, G., Yoon, B. and Park, J. (2010), "Open innovation in SMEs-An intermediated network model", Research Policy, Vol. 39, pp. 290-300.

Lendner, C. and Dowling, M. (2007), "The organisational structure of university business incubators and their impact on the success of start-ups: an international study", International Journal of Entrepreneurship and Innovation Management, Vol. 7 No. 6, pp. pp. 541-555.

Lerner, J. and Tirole, J. (2005), "The economics of technology sharing: Open source and beyond", Journal of economics perspectives, Vol. 19, No. 2, pp. 99-120.

Lerner, J., Pierrakis, Y., Collins, L. and Bravo Biosca, A. (2011), "Atlantic Drift: Venture capital performance in the UK and US", available at https://www.nesta.org.uk/sites/default/files/atlantic_drift.pdf (accessed 10 September 2015).

Malek, K., Maine, E. and McCarthy, I.P. (2014), "A typology of clean technology commercialization accelerators", Journal of Engineering and Technology Management, Vol. 32, pp. 26-39.

McAdam, M. and Marlow, S. (2007), "Building futures or stealing secrets? Entrepreneurial cooperation and conflict within business incubators", International Small Business Journal, Vol. 25 No. 4, pp. 361-382.

Miles, I. (2005), "Innovation in services", Fagerberg I. (Ed.), The Oxford handbook of innovation, Oxford: Oxford University Press, Oxford, pp. 433-458.

Miller, P. and Bound, K. (2011), "The Startup Factories: The Rise of Accelerator Programmes to Support New Technology Ventures", available at http://www.eban.org/wp-content/uploads/2014/09/14.-StartupFactories-TheRise-of-Accelerator-Programmes.pdf (accessed 10 September 2015).

Nambisan, S. and Sawhney, M. (2007), "A buyer's guide to the innovation bazaar", Harvard Business Review, Vol. 85 No. 6, pp. 109-18. 
Osterwalder, A. and Pigneur, Y. (2010), Business model generation: a handbook for visionaries, game changers, and challengers, Wiley, Hoboken, New Jersey.

Pauwels, C., Clarysse, B., Wright, M. and Van Hove, J. (2015), "Understanding a new generation incubation model: The accelerator", Technovation, http://dx.doi.org/10.1016/j.technovation.2015.09.003i

Phillips, B., Kirchhoff, D, Bruce, A. (1989), "Formation, Growth and Survival; Small Firm Dynamics in the U.S. Economy", Small Business Economics, Vol. 1 No. 1, pp. 65-74.

Powell, W.W., Koput, K.W., Smith-Doerr, L. (1996), "Interorganizational collaboration and the locus of innovation: Networks of learning in biotechnology", Administrative science quarterly, Vol. 41 No. 1, pp. 116-145.

Presutti, M., Boari, C. and Majocchi, A. (2011), "The importance of proximity for the start-ups' knowledge acquisition and exploitation", Journal of Small Business Management, Vol. 49, No. 3, pp. 361-389.

Rea, R.H. (1989), "Factors affecting success and failure of seed capital/start-up negotiations", Journal of Business Venturing, Vol. 4 No. 2, pp. 149-158.

Ries, E. (2011), The Lean Startup: How Today's Entrepreneurs Use Continuous Innovation to Create Radically Successful Businesses, Crown Business, United States.

Rothschild, L. and Darr, A. (2005) "Technological incubators and the social construction of innovation networks: An Israeli case", Technovation, Vol. 25 No. 1, pp. 59-67.

Schumpeter, J.A. (1934), The theory of economic development. Cambridge, MA: Harvard University Press.

Schwartz, M. (2013), "A control group study of incubators' impact to promote firm survival", The Journal of Technology Transfer, Vol. 38 No. 3, pp 302-331.

Scillitoe, J. and Chakrabarti, A. (2010), "The role of incubator interactions in assisting new ventures", Technovation, Vol. 30, pp. 155-167.

Shah, D., Wilkinson, M. and Yallup, K. (2008), "Analysis of the Factors Leading to Success or Failure of Start-Up Companies in the Field of Micro- and Nanotechnology", in Groen, A., Van Der Sijde, P., Oakey, R. and Cook, G. (Eds.), New Technology-Based Firms in the New Millennium, Volume 6, Emerald Group Publishing Limited, Bingley, UK, pp. 203-218.

Shane, S. (2001), "Technological opportunities and new firm creation”, Management Science, Vol. 47 No. 2, pp. 205220.

Song, M., Podoynitsyna, K., Van Der Bij, H. and Halman, J.I.M. (2008), "Success Factors in New Ventures: A Metaanalysis", Journal of Product Innovation Management, Vol. 25 No. 1, pp 7-27.

Stoetzel, M. (2012), "Engaging Mass Customization Customers beyond Product Configuration: Opportunities from the Open Innovation Field”, International Journal of Industrial Engineering and Management, Vol. 3 No. 4, pp. 241251.

Stuart, R. and Abetti, P.A. (1987), "Start-up ventures: Towards the prediction of initial success", Journal of Business Venturing, Vol. 2 No. 3, pp. 215-230.

Teal, E.J. and Hofer, C.W. (2003), "The Determinants of New Venture Success. Strategy, Industry Structure, and the Founding Entrepreneurial Team”, The Journal of Private Equity, Vol. 6 No. 4, pp. 38-51.

Trimi, S. and Berbegal-Mirabent, J. (2012), "Business model innovation in entrepreneurship", International Entrepreneurship and Management Journal, Vol. 8 No. 4, pp. 449-465.

van de Vrande, V., de Jong, J.P.J., Vanhaverbeke, W. and de Rochemont, M. (2009), "Open innovation in SMEs: Trends, motives and management challenges", Technovation, Vol. 29 Nos. 6-7, pp. 423-437.

von Hippel, E. (2007), "Horizontal innovation networks - by and for users", Industrial and Corporate Change, Vol. 16, No. 2, pp. 293-315.

Waguespack, D.M. and Fleming, L. (2009), "Scanning the commons? Evidence on the benefits to startups participating in open standards development”, Management Science, Vol. 55, No. 2, pp. 210-223.

Weiblen, T. and Chesbrough, H.W. (2015), "Engaging with startups to enhance corporate innovation", California management review, Vol. 57 No. 2, pp. 66-90.

West, J. and Bogers, M. (2014), "Leveraging external sources of innovation: a review of research on open innovation”, Journal of product innovation management, Vol. 31 No. 4, pp. 814-831.

Witt, J.K., Proffitt, D.R. and Epstein, W. (2004), "Perceiving distance: A role of effort and intent", Perception, Vol. 33, pp. 577-590.

Wong, P.K., Ho, Y.P., and Autio, E. (2005), "Entrepreneurship, innovation and economic growth: Evidence from GEM data", Small Business Economics, Vol. 24, pp. 335-350.

Yin, R.K. (2009), Case Study Research, Design and Methods, Sage Publications, Thousand Oaks, CA.

Zacharakis, A.L., Meyer, G.D. and DeCastro, J. (1999), "Differing perceptions of new venture failure: A matched exploratory study of venture capitalists and entrepreneurs", Journal of Small Business Management, Vol. 37 No. 3 , pp. 1-14. 


\begin{tabular}{|c|c|c|c|c|c|c|c|c|c|c|c|c|c|c|}
\hline \multirow{2}{*}{ 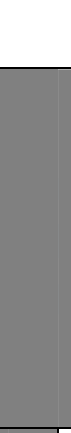 } & \multirow{2}{*}{ MAIN FAILURE FACTORS } & \multicolumn{13}{|c|}{ References } \\
\hline & & 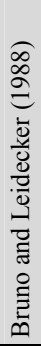 & 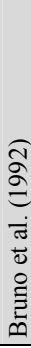 & 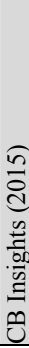 & 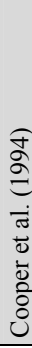 & 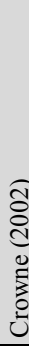 & 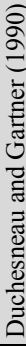 & 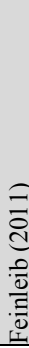 & 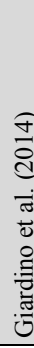 & ఠ & $\overline{\bar{c}}$ & & & $\frac{2}{5}$ \\
\hline \multirow{4}{*}{ 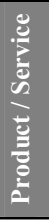 } & Wrong Time-to-Market & $\mathrm{x}$ & $\mathrm{x}$ & $\mathrm{x}$ & & $\mathrm{x}$ & & & & & & 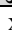 & & 5 \\
\hline & $\begin{array}{l}\text { Low level / Lack of innovation/ } \\
\text { technology }\end{array}$ & & & & & $\mathrm{x}$ & & & & & & 2 & & 4 \\
\hline & $\begin{array}{l}\text { Low or no product/market fit } \\
\text { (marketable product) }\end{array}$ & $\mathrm{x}$ & $\mathrm{x}$ & $\mathrm{x}$ & & $\mathrm{x}$ & & $\mathrm{x}$ & $\mathrm{x}$ & $\mathrm{x}$ & & & & 10 \\
\hline & $\begin{array}{l}\text { Need of patent protection and } \\
\text { licensing / Legal issue }\end{array}$ & & & $\mathrm{x}$ & & & & & & & & 2 & & 3 \\
\hline \multirow[b]{2}{*}{ 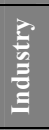 } & Unattractive market & & & & & & & & & $\mathrm{x}$ & & & & 2 \\
\hline & $\begin{array}{l}\text { High dynamics market / High } \\
\text { likelihood of potential entrance of } \\
\text { competitors }\end{array}$ & $\mathrm{x}$ & & $\mathrm{x}$ & & & & & $\mathrm{x}$ & & & & & 6 \\
\hline \multirow{3}{*}{ 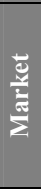 } & $\begin{array}{l}\text { Little (or none) Customer Feedback } \\
\text { / needs / involvement awareness }\end{array}$ & $\mathrm{x}$ & & $\mathrm{x}$ & & & & $\mathrm{x}$ & $\mathrm{x}$ & & $x$ & & & 7 \\
\hline & $\begin{array}{l}\text { Inappropriate Marketing / } \\
\text { Distribution / Selling strategy }\end{array}$ & $\mathrm{x}$ & $\mathrm{x}$ & & & & & & & & & & & 4 \\
\hline & $\begin{array}{l}\text { Low Marketing Intensity / Market } \\
\text { research }\end{array}$ & & & $\mathrm{x}$ & & & $\mathrm{x}$ & $\mathrm{x}$ & & & & & & 6 \\
\hline \multirow{3}{*}{ 疍 } & $\begin{array}{l}\text { High Overheads / Too far return on } \\
\text { investment / Run out of cash }\end{array}$ & $\mathrm{x}$ & $\mathrm{x}$ & $\mathrm{x}$ & & & & $\mathrm{x}$ & & $\mathrm{x}$ & & & & 6 \\
\hline & $\begin{array}{l}\text { Initial undercapitalization / Low } \\
\text { Capital Investment }\end{array}$ & $\mathrm{x}$ & $\mathrm{x}$ & & $\mathrm{x}$ & $\mathrm{x}$ & $\mathrm{x}$ & & & $\mathrm{x}$ & & & & 7 \\
\hline & $\begin{array}{l}\text { Little (or none) availability of } \\
\text { funding / financial support / } \\
\text { interested investors }\end{array}$ & $\mathrm{x}$ & $\mathrm{x}$ & $\mathrm{x}$ & & 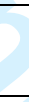 & & & & & & & & 7 \\
\hline \multirow{4}{*}{ 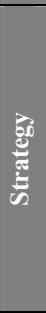 } & $\begin{array}{l}\text { Wrong ( or absent ) strategy } \\
\text { direction / positioning / scope }\end{array}$ & & & & & & $\mathrm{x}$ & & & & $\mathrm{x}$ & & & 5 \\
\hline & $\begin{array}{l}\text { Few (or none) focus on business } \\
\text { partners / partnerships / potential } \\
\text { alliances / networking }\end{array}$ & & & & $\mathrm{x}$ & & $\mathrm{x}$ & & & & & & & 5 \\
\hline & $\begin{array}{l}\text { Unclear (or none) Business Plan or } \\
\text { Business Model / Narrow Planning } \\
\text { Breadth / Low focus on long-term }\end{array}$ & $\mathrm{x}$ & $\mathrm{x}$ & $\mathrm{x}$ & & $\mathrm{x}$ & & & $\mathrm{x}$ & $x$ & $x$ & & & 8 \\
\hline & $\begin{array}{l}\text { Lack (or Low) use of professional } \\
\text { advices }\end{array}$ & & & & $\mathrm{x}$ & & & & ( & & & 2 & & 4 \\
\hline \multirow{7}{*}{ 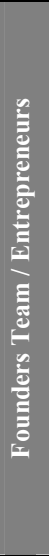 } & $\begin{array}{l}\text { Lose of focus due to personal or } \\
\text { communication and coordination } \\
\text { problems / absence of leadership }\end{array}$ & $\mathrm{x}$ & & $\mathrm{x}$ & & & & & $\mathrm{x}$ & & & & & 5 \\
\hline & $\begin{array}{l}\text { Low or missing entrepreneurial } \\
\text { experience }\end{array}$ & & & & $\mathrm{x}$ & & $\mathrm{x}$ & & & & & & & 4 \\
\hline & $\begin{array}{l}\text { Low or missing management- } \\
\text { specific know-how (e.g. marketing, } \\
\text { prior management experience) }\end{array}$ & & $\mathrm{x}$ & & $\mathrm{x}$ & $\mathrm{x}$ & $\mathrm{x}$ & & & & & & & 6 \\
\hline & $\begin{array}{l}\text { Low or missing industry specific } \\
\text { know-how }\end{array}$ & & & $\mathrm{x}$ & $\mathrm{x}$ & & & & & & & & & 4 \\
\hline & $\begin{array}{l}\text { Members background (education, } \\
\text { family, cultural / social diversity, } \\
\text { ethics and integrity) }\end{array}$ & & $\mathrm{x}$ & $\mathrm{x}$ & $\mathrm{x}$ & $\mathrm{x}$ & & & & & & & & 7 \\
\hline & $\begin{array}{l}\text { Narrow Breadth of vision / Low } \\
\text { flexibility to changes or risk } \\
\text { reduction }\end{array}$ & & & $\mathrm{x}$ & & & $\mathrm{x}$ & & & & & & & 3 \\
\hline & $\begin{array}{l}\text { Ineffective team / Low qualification } \\
\text { / expertise / skill diversity }\end{array}$ & $\mathrm{x}$ & $\mathrm{x}$ & $\mathrm{x}$ & & $\mathrm{x}$ & $\mathrm{x}$ & & $\mathrm{x}$ & $x$ & & & & 10 \\
\hline
\end{tabular}

Table 1 - Determinant factors of start-ups failure in literature 


\begin{tabular}{|c|c|c|}
\hline Practice & Definition & References \\
\hline Competitions / awards & $\begin{array}{l}\text { Invitation to participate in innovation challenges and } \\
\text { submit innovative ideas. }\end{array}$ & Chesbrough and Brunswicker, 2014 \\
\hline $\begin{array}{l}\text { Crowdsourcing / } \\
\text { communities }\end{array}$ & $\begin{array}{l}\text { The act of outsourcing a task in the problem solving } \\
\text { process to an undefined crowd (crowdsourcing) or to a } \\
\text { specific group (community), in the form of an open call. }\end{array}$ & Almirall et al., 2014; Chesbrough and Brunswicker, 2014 \\
\hline $\begin{array}{l}\text { Dyadic co-creation / } \\
\text { co-development in the } \\
\text { upstream network }\end{array}$ & $\begin{array}{l}\text { Involvement / Integration of one or multiple innovation } \\
\text { creators (suppliers) in the innovation process. }\end{array}$ & $\begin{array}{l}\text { Burcharth et al., 2014; Chesbrough and Brunswicker, } \\
\text { 2014; Gassman and Enkel, 2004; van de Vrande et al., } \\
\text { 2009 }\end{array}$ \\
\hline $\begin{array}{l}\text { Dyadic co-creation / } \\
\text { co-development in the } \\
\text { downstream network }\end{array}$ & $\begin{array}{l}\text { Involvement / Integration of one or multiple innovation } \\
\text { creators (consumers / customers / users / lead users) in } \\
\text { the innovation process. }\end{array}$ & $\begin{array}{l}\text { Brunswicker et al., 2012; Chesbrough and Brunswicker, } \\
\text { 2014; West and Bogers, } 2014\end{array}$ \\
\hline $\begin{array}{l}\text { Informal external } \\
\text { networking }\end{array}$ & $\begin{array}{l}\text { It includes all activities to acquire and maintain } \\
\text { connections with external sources of knowledge, } \\
\text { comprising both formal contractual collaborations and } \\
\text { more general and informal activities. }\end{array}$ & $\begin{array}{l}\text { Chesbrough and Brunswicker, 2014; Oliveira and Alves, } \\
\text { 2014; van de Vrande et al., } 2009\end{array}$ \\
\hline $\begin{array}{l}\text { Information } \\
\text { networking/ } \\
\text { Collecting information } \\
\text { from external sources } \\
\end{array}$ & $\begin{array}{l}\text { In this practice are included for example searching } \\
\text { internet for new trends or technology, reading technical } \\
\text { magazines, collecting information from other } \\
\text { organizations }\end{array}$ & Burcharth et al., 2014 \\
\hline Mass Customization & $\begin{array}{l}\text { Production of products which have been customized by } \\
\text { the customer, at production costs similar to those of } \\
\text { mass-produced products. }\end{array}$ & Stoetzel, 2012 \\
\hline $\begin{array}{l}R \& D \text { collaborations } \\
\text { and technology } \\
\text { alliances / consortia }\end{array}$ & $\begin{array}{l}\text { Cooperation (without equity involvement) between non- } \\
\text { competing firms with the aim to pursue a common } \\
\text { innovative objective }\end{array}$ & $\begin{array}{l}\text { Bianchi et al., 2011; Chesbrough and Brunswicker, 2014; } \\
\text { Gassman and Enkel, 2004; West and Bogers, } 2014\end{array}$ \\
\hline Technology Brokering & $\begin{array}{l}\text { To span multiple, otherwise disconnected industries, to } \\
\text { see how existing technologies could be used to create } \\
\text { breakthrough innovations in other markets }\end{array}$ & Hagardon and Sutton, 1997 \\
\hline Research grants & $\begin{array}{l}\text { Funding of external research projects by researchers } \\
\text { and scientists in universities (faculty, PhD students, or } \\
\text { postdoctoral fellows) to access external knowledge }\end{array}$ & Chesbrough and Brunswicker, 2014 \\
\hline
\end{tabular}

Table 2 - Main in-bound and coupled Open Innovation practices in SMEs 


\begin{tabular}{|c|c|c|c|c|c|c|c|c|c|c|c|c|c|c|}
\hline \multicolumn{8}{|c|}{ 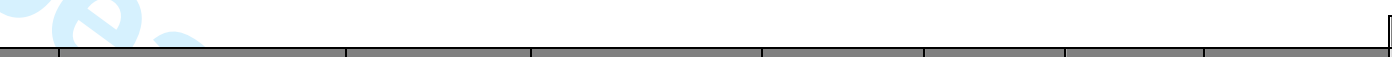 } & \multicolumn{7}{|c|}{ Services included in program package } \\
\hline$\#$ & Name & Location & Sector / industry & $\begin{array}{l}\text { Investment } \\
{[€]}\end{array}$ & $\begin{array}{l}\text { Share of } \\
\text { equity } \\
\text { required } \\
{[\%]}\end{array}$ & $\begin{array}{l}\text { Program } \\
\text { duration } \\
\text { [months] }\end{array}$ & $\begin{array}{l}\text { Accelerated } \\
\text { start-ups per } \\
\text { batch } \\
\text { [\#] }\end{array}$ & 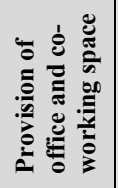 & 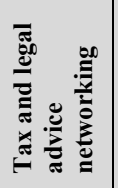 & 产竞 & 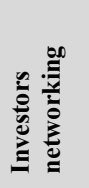 & 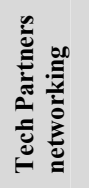 & 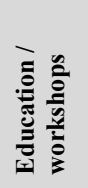 & 产 \\
\hline 1 & Accelerator Academy & London & Generic & $-3,500$ & N.A. & 3 & N.A. & $\mathrm{x}$ & $\mathrm{x}$ & $\mathrm{x}$ & $\mathrm{x}$ & $\mathrm{x}$ & $\mathrm{x}$ & $\mathrm{x}$ \\
\hline 2 & Bethnal Green Ventures & London & N.A. & 20,000 & $6 \%$ & 3 & 20 & & & $\mathrm{x}$ & $\mathrm{x}$ & & & $\mathrm{x}$ \\
\hline 3 & Cinnamon Bridge & London & Food and Beverage & N.A. & $10 \%$ & N.A. & 20 & & & & $\mathrm{x}$ & $\mathrm{x}$ & $\mathrm{x}$ & $\mathrm{x}$ \\
\hline 4 & Collider & London & Generic & 50,000 & $11 \%$ & 4 & 10 & $\mathrm{x}$ & $\mathrm{x}$ & $\mathrm{x}$ & $\mathrm{x}$ & $\mathrm{x}$ & $\mathrm{x}$ & $\mathrm{x}$ \\
\hline 5 & $\begin{array}{l}\text { Dotforge Impact } \\
\text { Accelerator }\end{array}$ & Manchester & Social & 25,000 & N.A. & 3 & N.A. & $\mathrm{x}$ & & $\mathrm{x}$ & $\mathrm{x}$ & $\mathrm{x}$ & $\mathrm{x}$ & $\mathrm{x}$ \\
\hline 6 & Emerge Education & London & Education & 20,000 & $8 \%$ & 8 & 16 & $\mathrm{x}$ & & $\mathrm{x}$ & $\mathrm{x}$ & $\mathrm{x}$ & $\mathrm{x}$ & $\mathrm{x}$ \\
\hline 7 & Fintech Innovation Lab & London & Fintech & N.A. & N.A. & 3 & N.A. & $\mathrm{x}$ & & & $\mathrm{x}$ & & $\mathrm{x}$ & $\mathrm{x}$ \\
\hline 8 & Entrepreneur First & London & Generic & 24,000 & $8 \%$ & 4 & N.A. & $\mathrm{x}$ & & $\mathrm{x}$ & $\mathrm{x}$ & $\mathrm{x}$ & $\mathrm{x}$ & $\mathrm{x}$ \\
\hline 9 & Healthbox Europe & London & Healthcare & 65,000 & $10 \%$ & 4 & 7 & & & & $\mathrm{x}$ & $\mathrm{x}$ & & $\mathrm{x}$ \\
\hline 10 & Ignite100 & Newcastle & Generic & 23,000 & $8 \%$ & 3 & 10 & $\mathrm{x}$ & $\mathrm{x}$ & $\mathrm{x}$ & $\mathrm{x}$ & $\mathrm{x}$ & $\mathrm{x}$ & $\mathrm{x}$ \\
\hline 11 & $J L A B$ & London & Retail & 27,000 & N.A. & 3 & N.A. & $\mathrm{x}$ & & & $\mathrm{x}$ & $\mathrm{x}$ & $\mathrm{x}$ & $\mathrm{x}$ \\
\hline 12 & Microsoft Ventures & London & Generic & 0 & $0 \%$ & 3 & N.A. & $\mathrm{x}$ & & $\mathrm{x}$ & $\mathrm{x}$ & $\mathrm{x}$ & $\mathrm{x}$ & $\mathrm{x}$ \\
\hline 13 & Oxygen Accelerator & Birmingham & Generic & 21,000 & $8 \%$ & 3 & 10 & $\mathrm{x}$ & $\mathrm{x}$ & $\mathrm{x}$ & $\mathrm{x}$ & $\mathrm{x}$ & $\mathrm{x}$ & $\mathrm{x}$ \\
\hline 14 & PiLabs & London & Generic & 27,000 & $7 \%$ & 3 & 15 & $\mathrm{x}$ & $\mathrm{x}$ & $\mathrm{x}$ & $\mathrm{x}$ & $\mathrm{x}$ & $\mathrm{x}$ & $\mathrm{x}$ \\
\hline 15 & SearchCamp & \begin{tabular}{|l|} 
Middlesbrough \\
\end{tabular} & Internet / mobile & 20,000 & $10 \%$ & 3 & 8 & $\mathrm{x}$ & $\mathrm{x}$ & $\mathrm{x}$ & $\mathrm{x}$ & $\mathrm{x}$ & $\mathrm{x}$ & $\mathrm{x}$ \\
\hline 16 & SeedCamp & London & Generic & 25,000 & $5 \%$ & 3 & 15 & $\mathrm{x}$ & $\mathrm{x}$ & $\mathrm{x}$ & $\mathrm{x}$ & $\mathrm{x}$ & $\mathrm{x}$ & $\mathrm{x}$ \\
\hline 17 & SpringBoard & Cambridge & Generic & 20,000 & $6 \%$ & 3 & 10 & $\mathrm{x}$ & & $\mathrm{x}$ & $\mathrm{x}$ & & $\mathrm{x}$ & $\mathrm{x}$ \\
\hline 18 & Startdoms Virtual & \begin{tabular}{|l} 
Leicester \\
\end{tabular} & Generic & N.A. & N.A. & 3 & N.A. & & & & $\mathrm{x}$ & $\mathrm{x}$ & $\mathrm{x}$ & $\mathrm{x}$ \\
\hline 19 & \begin{tabular}{|l|} 
StartPlanet NI \\
Accelerator \\
\end{tabular} & Belfast & Generic & 20,000 & $8 \%$ & 3 & 10 & $\mathrm{x}$ & $\mathrm{x}$ & $\mathrm{x}$ & $\mathrm{x}$ & $\mathrm{x}$ & $\mathrm{x}$ & $\mathrm{x}$ \\
\hline 20 & Startup Bootcamp & London & Generic & 20,000 & $8 \%$ & 4 & 10 & $\mathrm{x}$ & $\mathrm{x}$ & $\mathrm{x}$ & $\mathrm{x}$ & $\mathrm{x}$ & $\mathrm{x}$ & $\mathrm{x}$ \\
\hline 21 & \begin{tabular}{|l|} 
TechStars \\
\end{tabular} & London & Generic & 16,000 & $10 \%$ & 3 & 10 & $\mathrm{x}$ & & $\mathrm{x}$ & $\mathrm{x}$ & $\mathrm{x}$ & $\mathrm{x}$ & $\mathrm{x}$ \\
\hline 22 & True Start & London & Retail & 35,000 & $10 \%$ & 6 & N.A. & $\mathrm{x}$ & $\mathrm{x}$ & $\mathrm{x}$ & $\mathrm{x}$ & $\mathrm{x}$ & $\mathrm{x}$ & $\mathrm{x}$ \\
\hline 23 & UpAccelerator & Edinburgh & Generic & 34,000 & N.A. & N.A. & 20 & $\mathrm{x}$ & $\mathrm{x}$ & $\mathrm{x}$ & $\mathrm{x}$ & $\mathrm{x}$ & $\mathrm{x}$ & $\mathrm{x}$ \\
\hline 24 & WHLabs (William Hills) & London & WH related & 34,000 & N.A. & 3 & 8 & & & & & $\mathrm{x}$ & & $\mathrm{x}$ \\
\hline
\end{tabular}

Table 3 - UK accelerators: main features and services 


\begin{tabular}{|c|c|c|}
\hline$\overline{\text { SERVICE }}$ & \multicolumn{2}{|l|}{ TOOLS AND PRACTICES } \\
\hline $\begin{array}{l}\text { Provision of office and } \\
\text { co-working space }\end{array}$ & Office space & $\begin{array}{l}\text { Office space tailored for start-ups where founders have } 24 \mathrm{~h} \text { access to work on } \\
\text { their business / product / service development and to meet external partners }\end{array}$ \\
\hline \multirow[b]{2}{*}{$\begin{array}{l}\text { Tax and legal advice } \\
\text { networking }\end{array}$} & SEIS application & $\begin{array}{l}\text { Registration to national SEIS ((Seed Enterprise Investment Scheme) program } \\
\text { that incentivises investments by providing tax cuts for people and institutions } \\
\text { investing in early-stage start-ups }\end{array}$ \\
\hline & Tax and legal advice & $\begin{array}{l}\text { Advice and face-to-face meetings with experts on legal issues such as } \\
\text { intellectual property, trademarks, privacy policy, terms and conditions for } \\
\text { websites, VAT (Value Added Tax) registration, societal and personal } \\
\text { obligations }\end{array}$ \\
\hline Start-ups networking & Local press and websites & Promotion of participating start-ups in local press and industry websites \\
\hline \multirow{2}{*}{ Investors networking } & Investors meetings & $\begin{array}{l}\text { Face to face meetings at office space with investors such as business angels and } \\
\text { venture capitalists }\end{array}$ \\
\hline & Demo days & $\begin{array}{l}\text { Events where start-ups founders present their product or service to an audience } \\
\text { of investors }\end{array}$ \\
\hline $\begin{array}{l}\text { Tech Partners } \\
\text { networking }\end{array}$ & $\begin{array}{l}\text { CTO (Chief Technology Officer) } \\
\text { and computer experts }\end{array}$ & Experts in computer science stable or coming to office space \\
\hline \multirow{10}{*}{ Education / workshops } & The Value Proposition Canvas & $\begin{array}{l}\text { It helps in describing explicitly how company product or service creates value } \\
\text { for customer (Osterwalder and Pigneur, 2010). It helps in raising awareness of } \\
\text { product/market fit by highlighting "gains" and "pains" both for company and } \\
\text { for potential customers }\end{array}$ \\
\hline & The Business Model Canvas & $\begin{array}{l}\text { It aims at revealing how a company create, deliver and capture value and then } \\
\text { how strategy is implemented through organisational structures, processes and } \\
\text { systems. It is useful as a blueprint to frame key building blocks (Osterwalder } \\
\text { and Pigneur, 2010). }\end{array}$ \\
\hline & The Lean start-up Loop & $\begin{array}{l}\text { Build-Measure-Learn Loop that aims to create the so-called Minimum Viable } \\
\text { Product as a first version of the product, able to deliver main value for customer } \\
\text { (initially without secondary functions); after measuring customers respond it } \\
\text { can be further improved following feedbacks or completely changed - realising } \\
\text { a "pivot" in redirecting business (Ries, 2011) }\end{array}$ \\
\hline & The Kanban Board & Visual tool used to optimising workflows \\
\hline & $\begin{array}{l}\text { The Four Step to Customer } \\
\text { Development }\end{array}$ & $\begin{array}{l}\text { Process of four steps: 1) customer discovery (identification of a business idea } \\
\text { that can solve a real problem), 2) customer validation (evaluation of idea } \\
\text { marketability), 3) customer creation, 4) company building (transforming idea in } \\
\text { a real business) (Blank and Dorf, 2012) }\end{array}$ \\
\hline & Analytics tools Masterclass & Advice on how to implement analytics systems to study customers behaviour \\
\hline & Customer interviews and feedbacks & $\begin{array}{l}\text { Advice on how to implement systems collecting feedbacks, complaints and } \\
\text { specific needs of customers }\end{array}$ \\
\hline & Sales and marketing Masterclass & Advice on how to better improve sales, marketing and distribution strategy \\
\hline & Facebook advertising Masterclass & $\begin{array}{l}\text { Advice on how to use "Facebook for Business" tool that allows companies to } \\
\text { create commercial sections and advertisements and to elaborate information on } \\
\text { user preferences in order to deliver more valuable and customised products or } \\
\text { services }\end{array}$ \\
\hline & Raise capital Masterclass & Advice on how to attract investors and obtain funding \\
\hline \multirow{2}{*}{ Mentorship } & Mentors feedbacks & $\begin{array}{l}\text { Face-to-face meetings with mentors (also external) in order to constantly collect } \\
\text { feedbacks and advice }\end{array}$ \\
\hline & Pitch Coaching & $\begin{array}{l}\text { Preparation for the "pitch", namely a brief speech to convince audience of } \\
\text { investors and other potential partners of product / service innovative value }\end{array}$ \\
\hline
\end{tabular}

Table 4 - Services and tools in Searchcamp accelerator 


\begin{tabular}{|c|c|c|c|c|c|c|c|c|c|c|c|}
\hline \multirow[b]{2}{*}{ SERVICE } & \multirow[b]{2}{*}{ TOOLS AND PRACTICES } & \multicolumn{10}{|c|}{ OPEN INNOVATION } \\
\hline & & 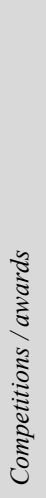 & 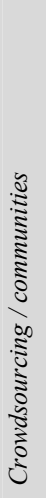 & 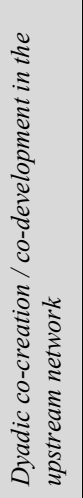 & 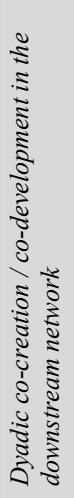 & 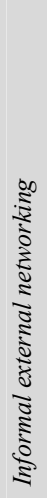 & 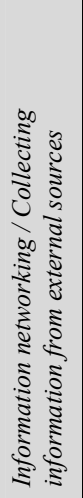 & 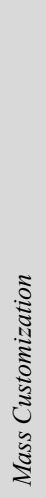 & 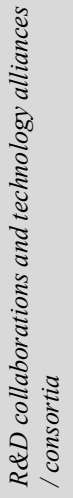 & 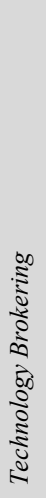 & 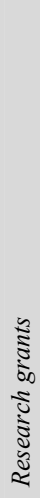 \\
\hline $\begin{array}{l}\text { Provision of } \\
\text { office and } \\
\text { co-working } \\
\text { space }\end{array}$ & Office space & & & $\mathrm{x}$ & $\mathrm{x}$ & $\mathrm{x}$ & $\mathrm{x}$ & & $\mathrm{x}$ & $\mathrm{x}$ & \\
\hline \multirow{2}{*}{$\begin{array}{l}\text { Tax and } \\
\text { legal advice } \\
\text { networking }\end{array}$} & SEIS application & & & & & & & & & & \\
\hline & Tax and legal advice & & & & & & & & & & \\
\hline $\begin{array}{l}\text { Start-ups } \\
\text { networking }\end{array}$ & Local press and websites & & & & & $\mathrm{x}$ & $\mathrm{x}$ & & & & \\
\hline \multirow{2}{*}{$\begin{array}{l}\text { Investors } \\
\text { networking }\end{array}$} & Investors meetings & $\mathrm{x}$ & & & & $\mathrm{x}$ & $\mathrm{x}$ & & & $\mathrm{x}$ & $\mathrm{x}$ \\
\hline & Demo days & $\mathrm{x}$ & & & & $\mathrm{x}$ & $\mathrm{x}$ & & & $\mathrm{x}$ & $\mathrm{x}$ \\
\hline $\begin{array}{l}\text { Tech } \\
\text { Partners } \\
\text { networking }\end{array}$ & $\begin{array}{l}\text { CTO (Chief Technology } \\
\text { Officer) and computer experts }\end{array}$ & & & $\mathrm{x}$ & $\mathrm{x}$ & $\mathrm{x}$ & $\mathrm{x}$ & & $\mathrm{x}$ & $\mathrm{x}$ & \\
\hline \multirow{10}{*}{$\begin{array}{l}\text { Education / } \\
\text { workshops }\end{array}$} & $\begin{array}{l}\text { The Value Proposition } \\
\text { Canvas }\end{array}$ & & & $\mathrm{x}$ & $\mathrm{x}$ & & & & & & \\
\hline & The Business Model Canvas & & & $\mathrm{x}$ & $\mathrm{x}$ & & & & & & \\
\hline & The Lean start-up Loop & & & & & & & & & & \\
\hline & The Kanban Board & & & & & & & & & & \\
\hline & $\begin{array}{l}\text { The Four Step to Customer } \\
\text { Development }\end{array}$ & & $\mathrm{x}$ & & $\mathrm{x}$ & & & & & & \\
\hline & Analytics tools Masterclass & & & & & & & & & & \\
\hline & $\begin{array}{l}\text { Customer interviews and } \\
\text { feedbacks }\end{array}$ & & $\mathrm{x}$ & & $\mathrm{x}$ & & & & & & \\
\hline & $\begin{array}{l}\text { Sales and marketing } \\
\text { Masterclass }\end{array}$ & & $\mathrm{x}$ & & $\mathrm{x}$ & & & & & & \\
\hline & $\begin{array}{l}\text { Facebook advertising } \\
\text { Masterclass }\end{array}$ & & $\mathrm{x}$ & & $\mathrm{x}$ & & & & & & \\
\hline & Raise capital Masterclass & & & & & & & & & & \\
\hline \multirow{2}{*}{ Mentorship } & Mentors feedbacks & & & & & $\mathrm{x}$ & $\mathrm{x}$ & & & $\mathrm{x}$ & $\mathrm{x}$ \\
\hline & Pitch Coaching & & & & & & $\mathrm{x}$ & & & $\mathrm{x}$ & \\
\hline
\end{tabular}

Table 5 - Tools and practices of accelerator as open innovation practices 


\section{MAIN FAILURE FACTORS}

\& Wrong Time-to-Market

Low level / Lack of innovation/ technology

Low or no product/ market fit (marketable product)

Need of patent protection and licensing / Legal

Unattractive market

High dynamics market / High likelihood of

potential entrance of competitors

Little (or none) Customer Feedback / needs

involvement awareness

Inappropriate Marketing / Distribution / Selling strategy

Low Marketing Intensity / Market research High Overheads / Too far return on investment Run out of cash

Initial undercapitalization / Low Capital
Investment

Investment

Little (or none) availability of funding / financial

support / interested investors

Wrong ( or absent ) strategy direction /

positioning / scope

Few (or none) focus on business partners /

partnerships / potential alliances / networking

Unclear (or none) Business Plan or Business

Model / Narrow Planning Breadth / Low focus

on long-term

Lack (or Low) use of professional advices

Lose of focus due to personal or communication

and coordination problems / absence of

leadership

Low or missing entrepreneurial experience

Low or missing management-specific know-how

(e.g. marketing, prior management experience)

Low or missing industry specific know-how

\begin{tabular}{|c|c|c|c|c|c|c|c|c|c|c|}
\hline \multicolumn{10}{|c|}{ OPEN INNOVATION PRACTICES } & \multirow[b]{2}{*}{ 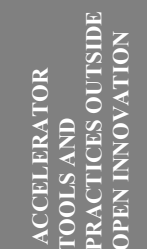 } \\
\hline 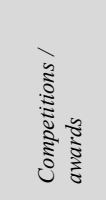 & 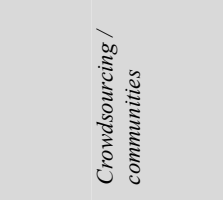 & 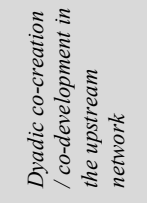 & 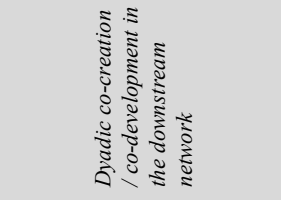 & 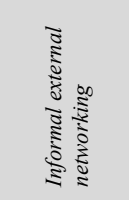 & 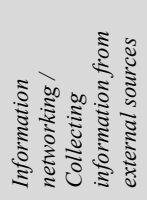 & 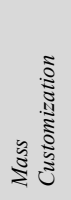 & 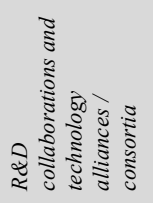 & 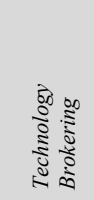 & 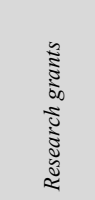 & \\
\hline & 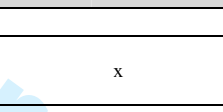 & $\begin{array}{l}\text { CTO and } \\
\text { computer } \\
\text { experts }\end{array}$ & $\mathrm{x}$ & $\mathrm{x}$ & $\mathrm{x}$ & & $\begin{array}{l}\text { CTO and } \\
\text { computer } \\
\text { experts }\end{array}$ & & $\mathrm{x}$ & \\
\hline$x^{2}$ & $\mathrm{x}$ & & The Value Proposition Canvas & & & $\mathrm{x}$ & & & & $\begin{array}{l}\text { The Lean start-up } \\
\text { Loop } \\
\end{array}$ \\
\hline & $\sqrt{2+2}$ & & & & & & $\mathrm{x}$ & & & $\begin{array}{l}\text { Tax and legal } \\
\text { advice }\end{array}$ \\
\hline & +2 & & $\mathrm{x}$ & & & & & & & $\begin{array}{l}\text { Analytics tools } \\
\text { Masterclass }\end{array}$ \\
\hline & Y & $\mathrm{x}$ & $\mathrm{x}$ & & & & $\mathrm{x}$ & & & \\
\hline & $\begin{array}{l}\text { Customer interviews / } \\
\text { feedbacks; The Four Step } \\
\text { to Customer Development }\end{array}$ & & $\begin{array}{l}\text { Customer interviews / feedbacks; } \\
\text { The Four Step to Customer } \\
\text { Development }\end{array}$ & & $\mathrm{x}$ & & & & & $\begin{array}{l}\text { The Lean start-up } \\
\text { Loop; Analytics } \\
\text { tools Masterclass }\end{array}$ \\
\hline & $\begin{array}{l}\text { Sales and marketing } \\
\text { Masterclass; } \\
\text { Facebook advertising } \\
\text { Masterclass }\end{array}$ & & $\begin{array}{l}\text { Sales and marketing Masterclass; } \\
\text { Facebook advertising Masterclass }\end{array}$ & & $\mathrm{x}$ & $\mathrm{x}$ & & & & \\
\hline & $\begin{array}{l}\text { Sales and marketing } \\
\text { Masterclass }\end{array}$ & & Sales and marketing Masterclass & $\mathrm{x}$ & $\mathrm{x}$ & & & & & \\
\hline & & & & & & & $\mathrm{x}$ & & & $\begin{array}{l}\text { Tax and legal } \\
\text { advice; The } \\
\text { Business Model } \\
\text { Canvas }\end{array}$ \\
\hline $\mathrm{x}$ & & & & & & & & & & \\
\hline $\begin{array}{l}\text { Investors } \\
\text { meetings; } \\
\text { Demo days }\end{array}$ & & & & & & & & & & $\begin{array}{l}\text { Raise capital } \\
\text { Masterclass }\end{array}$ \\
\hline & & & & $x^{2}$ & $\mathrm{x}$ & & & & & $\begin{array}{l}\text { The Business } \\
\text { Model Canvas }\end{array}$ \\
\hline & & $\begin{array}{l}\text { The Business } \\
\text { Model Canvas }\end{array}$ & & & & & & & $\begin{array}{l}\text { CTO and } \\
\text { computer } \\
\text { experts }\end{array}$ & \\
\hline & & & & $\mathrm{x}$ & $\mathrm{x}$ & & & & & $\begin{array}{l}\text { The Kanban } \\
\text { Board }\end{array}$ \\
\hline & & Office space & Office space & Office space & Office space & - & Office space & $\begin{array}{l}\begin{array}{l}\text { Office } \\
\text { space }\end{array} \\
\end{array}$ & & \\
\hline & & $\mathrm{x}$ & & & & & $\mathrm{x}$ & 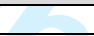 & & Mentors feedback \\
\hline & & $\begin{array}{l}\text { The Value } \\
\text { Proposition } \\
\text { Canvas; The } \\
\text { Business Model } \\
\text { Canvas }\end{array}$ & $\begin{array}{l}\text { The Value Proposition Canvas; } \\
\text { The Business Model Canvas; The } \\
\text { Four Step to Customer } \\
\text { Developenent; Customer } \\
\text { interviews feedbacks; Sales and } \\
\text { marketing Masterclass; Facebook } \\
\text { advertising Masterclass }\end{array}$ & & & & $\mathrm{x}$ & & & $\begin{array}{l}\text { The Kanban } \\
\text { Board }\end{array}$ \\
\hline & $\mathrm{x}$ & $\begin{array}{l}\text { CTO and } \\
\text { computer }\end{array}$ & CTO and computer experts & $\begin{array}{l}\text { CTO and } \\
\text { computer }\end{array}$ & $\begin{array}{l}\text { CTO and } \\
\text { computer }\end{array}$ & & & $\begin{array}{l}\text { CTO and } \\
\text { computer }\end{array}$ & & ser \\
\hline
\end{tabular}




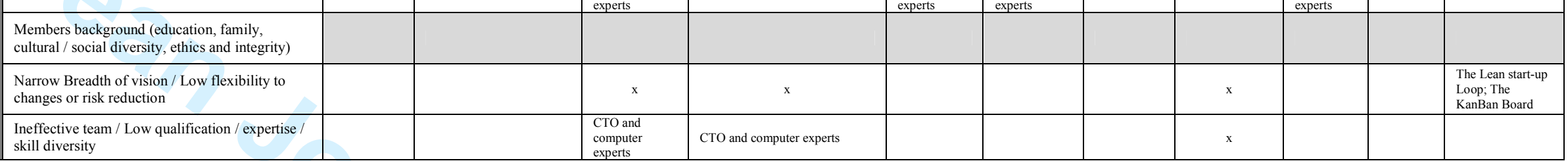

Table 6 - Open Innovation practices and accelerators tools for mitigating start-ups failure 